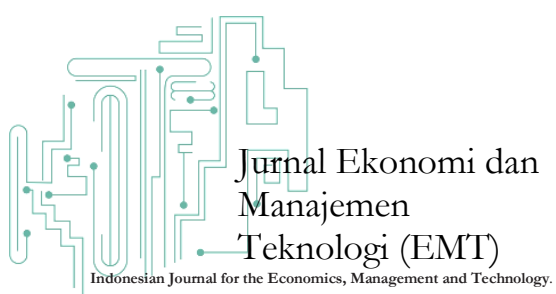

Jurnal Ekonomi dan Manajemen Teknologi, $4(1), 2020,11-18$

Available online at http://journal.lembagakita.org

\title{
Model Marketplace Berbasis Kearifan Lokal
}

\author{
Tarmizi $^{1}$, Ismail ${ }^{2}$ \\ ${ }^{1}$ STMIK Indonesia Banda Aceh \\ 2 AMIK Indonesia
}

\begin{abstract}
Abstrak. Penelitian ini bertujuan untuk membuat model marketplace berbasis kearifan lokal, sehingga kegiatan pemasaran pelaku usaha kecil dapat berjalan dengan efektif. Untuk membuktikan efektifitas media pemasaran digital berupa marketplace, maka diperlukan subyek penelitian yaitu pelaku usaha kecil yang terlibat langsung dengan pemasaran online, pendekatan wawancara dan tingkat keberhasilan mereka dalam penggunaan media digital (marketplace) tersebut. Melalui penelitian ini diharapkan pelaku usaha kecil dapat memilih secara bijak dan efektif penggunaan media digital (marketplace) dalam kegiatan pemasaran mereka sehingga omzet penjualan mereka dapat meningkat. Penelitian mengambil lokasi atau obyek penelitian di kota Banda Aceh. Mengingat perilaku konsumen pada kota Banda Aceh tersebut berbeda satu sama lain, tentunya harus dapat diukur dan diuji, apakah model yang marketplace berbasis kearifan lokal dapat diterapkan dan memiliki bubungan secara signifikan guna peningkatan kegiatan pemasaran dan penjualan produk. pelaku usaha. Jenis Penelitian ini menggunakan penelitian kualitatif deskripstif, analisis data di lapangan terhadap model dan metode penelitiannya dilakukan dengan mewawancarai beberapa pelaku UMKM dan pengguna marketplace lokal di Kota Banda Aceh. Sampel dalam penelitian ini adalah pelaku usaha kecil yang aktif menggunakan marketplace selama dua tahun terakbir dalam proses pemasaran dan penjualan produk. mereka di pasar online. Dari hasil penetapan sampel secara non random sampling tersebut, diperoleh sebanyak 173 responden yang umumnya adalah pelaku usaha kecil. Teknik pengumpulan data menggunakan model interview dan kuisioner, dan model analisa yang digunakan disini adalah Uji Crosstabs. Berdasarkan hasil survey dan wawancara dengan beberapa pelaku usaha, diperoleh hasil bahwa ada model marketplace berbasis kearifan local memiliki bubungan yang sangat signifikan dalam meningkatkan pendapatan pelaku usaha kecil memasarkan dan menjual produknya secara online di Kota Banda Aceh.
\end{abstract}

Kata kunci: Marketplace, Pelaku usaha kecil, Kearifan Lokal.

Abstract. This study aims to create a market model based on local wisdom so that the marketing activities of small businesses can run effectively. To prove the effectiveness of digital marketing media in the form of a marketplace, research subjects are needed, namely small businesses involved directly with online marketing, interview approaches, and their success rate in using digital media (marketplaces). Through this research, it is expected that small businesses can choose wisely and effectively the use of digital media (marketplaces) in their marketing activities so that their sales turnover can increase. The study took the location or object of research in the city of Banda Aceh. Considering that consumer behavior in the city of Banda Aceh is different from one another, of course, it must be measured and tested, whether the market model based on local wisdom can be applied and has a significant relationship to increase marketing activities and product sales of business actors. This type of research uses descriptive qualitative research, data analysis in the field of the research model and method is carried out by interviewing several SMEs and local marketplace users in the city of Banda Aceh. The sample in this study is small business practitioners who actively use the marketplace for the past two years in the process of marketing and selling their products in the online market. From the results of the non-random sampling, 173 respondents were generally employed, who were small businesses. Data collection techniques using interview and questionnaire models, and the analysis model used here is the Crosstabs Test. Based on the results of surveys and interviews with several business actors, it was found that there is a marketplace model based on local wisdom that has a very significant relationship in increasing the income of small businesses marketing and selling their products online in Banda Aceh City.

Keywords: Marketplace, Small business actors, Local Wisdom.

*Corresponding author. Email: tarmizi@stmikiba.ac.id ${ }^{1}$

DOI: https://doi.org/10.35870/emt.v4i1.125

Received: 15 March 2020, Revision: 19 April 2020, Accepted: 20 April 2020

Print ISSN: 2579-7972; Online ISSN: 2549-6204.

Copyright@2020. Published by Lembaga Otonom Lembaga Informasi dan Riset Indonesia (KITA INFO dan RISET). 


\section{Pendahuluan}

Kehadiran marketplace sekarang ini banyak membantu kebutuhan masyarakat. Apa saja ada di marketplace (Utami dan Trisna, 2019). Anda baru pindah rumah dan membutuhkan furniture penting, Anda bisa menemukan beragam variasi furnitur dengan harga yang bersaing. Tidak hanya furnitur, ada pula kebutuhan primer seperti fashion, makanan hingga kebutuhan daily (Setyaningrum dan Tontowi, 2014). Misalnya membeli tiket bioskop, membayar pulsa, bayar rekening PDAM hingga membeli pulsa. Semua itu bisa dilakukan dengan bantuan marketplace. Melihat betapa banyak aktivitas dihabiskan menggunakan marketplace sebagai pemenuhan kebutuhan sehari-hari, inilah yang membuat marketplace ini diburu. Tidak hanya oleh pengguna tapi juga investor. Antusias masyarakat semakin meninggi karena didukung infrastruktur yang memadai dan akses yang mudah. Badan Koordiansi Penanaman Modal (BKPM) mengungkapkan nilai investasi di sektor pasar digital pada 2017 mencapai USD 5 miliar. Hal ini menjadikan marketplace sebagai sektor ekonomi yang paling diburu saat ini (Outletz.ID, 2018). Tahun 2015 sepertinya adalah tahun yang menandakan banyak bermunculannya startup yang bergerak di industri e-commerce (Utoyo, 2016). Marketplace merupakan salah satu konsep bisnis yang digunakan oleh para e-commerce tersebut. Sebelum membahas lebih lanjut, ada baiknya kita mengenal apa itu marketplace (Arwiedya dan Sugiarto, 2011).

Marketplace memiliki konsep seperti pasar tradisional yang seakan-akan berada di internet (Permana dan Hadi, 2019). Pemilik marketplace memiliki peran sebagai pihak yang mempertemukan antara penjual dengan pembeli pada website mereka (Yustiani dan Yunanto, 2017). Beberapa situs e-commerce seperti Blibli dan Blanja merupakan contoh situs yang mengkurasi penjualnya (Hadi Soeprayitno Putra, 2016). Adapula yang bebas membuka kesempatan bagi semua orang untuk menjadi penjual, seperti elevenia, Tokopedia, dan Bukalapak (Qomarudin, 2019; Qulub, 2019; Alfarizi, 2019). Model seperti inilah yang disebut dengan marketplace. Dengan mengusung konsep marketplace, e-commerce bisa berkembang dengan cepat. Akan tetapi konsep seperti ini juga dapat menjadi bumerang apabila tidak berhatihati. Melihat manfaat dan keuntungannya yang luas, sudah tentu penggunaan marketplace akan banyak bermanfaat dan membantu tumbuh kembangnya pelaku usaha kecil yang memiliki produk berpotensi dan dibutuhkan oleh pasar.

Berubahnya perilaku berbelanja penduduk Indonesia mulai tahun 2011 hingga sekarang membuat semakin pesatnya pertumbuhan marketplace di negara Indonesia (Susanto, 2012). Konsumen cenderung menyukai belanja online karena cenderung lebih praktis, modern, dapat dilakukan setiap waktu tanpa harus susah melakukan mobilitas keluar rumah ketika membutuhkan barang yang diinginkan (Albi dan Luqni, 2018; Widiana, Hidayati, dan Karsam, 2019). Sudah tentu hal ini merupakan peluang bagus bagi sebagian besar pelaku usaha kecil untuk ikut berperan aktif dalam menawarkan barang dagangan mereka menggunakan marketplace di Indonesia. Tentunya kondisi ini memberikan peluang dan keuntungan yang cukup besar bagi pelaku usaha yang ingin menjajakan barang mereka pada marketplace yang telah memiliki reputasi bagus di Indonesia. Menurut pemaparan Handayani (2017) membahas mengenai peran e-commerce yang menunjang berkembangnya kegiatan perdagangan secara online memlalui keputusan pembelian yang dilakukan oleh konusmen, pada kesempatan lain Majid (2017) penerapan ecommerce di Indonesia dipandang dari sudut persepsi dan kepercayaan konsumen dalam melaksanakan transaksi secaca online pada beberapa marketplace terkemuka di Indonesia.

Marketplace saat ini menjadi peluang besar sebagai promosi bisnis mereka. Penggunakan market place dapat memberikan efisiensi anggaran pemasaran karena marketplace memiliki jangkauan yang luas, akses mudah dan biaya murah. Namun marketplace yang ada selama ini hanya berfokus pada kegiatan virtual antara pembeli dan penjual tanpa membawa nilai kearifan lokal pada sistem marketplacenya. Sehingga konsep jual beli barang secara online seperti terkesan hanya berfokus pada nilai kecanggihan semata tanpa melihat nilai kearifan lokal daerah yang dapat membentuk karakteristik bangsa yang unggul melalui aktifitas yang mereka kerjakan. Karena alasan inilah penulis tertarik untuk melakukan penelitian 
terkait dengan Model Marketplace Lokal Berbasis Kearifal Lokal.

\section{Literature Review}

\section{Marketplace}

Marketplace merupakan media online berbasis internet (web-based) tempat melakukan kegiatan bisnis dan transaksi antara pembeli dan penjual. Pembeli dapat mencari supplier sebanyak mungkin dengan kriteria yang diinginkan, sehingga memperoleh sesuai harga pasar. Sedangkan bagi supplier/penjual dapat mengetahui perusahaan-perusahaan yang membutuhkan produk/jasa mereka (Karmila dan Rusda, 2019).

Marketplace merupakan model E-Business yang berhubungan dengan penjual dan pembeli (Seller dan Buyer). Marketplace di Indonesia merupakan salah satu media penggerak ekonomi nasional dalam rangka menghadapi era globalisasi (Anggono, 2020). Untuk itu, perlu dikembangkan marketplace yang teratur, wajar dan efisien. Pada umumnya marketplace yang efisien dapat meningkatkan iklim investasi di perusahaan dan memudahkan arus input dan output barang. Perkembangan teknologi memberikan cakrawala baru bagi mereka yang ingin maju. Hadirnya berbagai produk dari hasil perkembangan teknologi ini salah satunya adalah marketplace. Secara sederhana marketplace ialah sebuah pasar di mana penjual dan pembeli bertukar barang dan jasa untuk uang, atau barang dan jasa lainnya, yang dilakukan secara elektronis.

Outletz (2018) mengatakan situs e-commerce mampu membantu pelaku UMKM dalam memasarkan produknya dengan murah dan efektif dan marketplace sebagai sektor ekonomi yang paling diburu saat ini. Situs marketplace telah menjadi alternative dalam memprosikan produk ke berbagai daerah di samping sengitnya persaingan industry e-commerce nasional dewasa ini.

\section{UMKM}

Di Indonesia UMKM diatur dalam UndangUndang Republik Indonesia No.20 Tahun 2008 tentang UMKM. Pasal 1 dari UU terebut, dinyatakan bahwa Usaha mikro adalah usaha produktif milik orang perorangan dan/atau badan usaha perorangan yang memiliki kriteria usaha mikro sebagaimana diatur dalam UU tersebut. Usaha kecil adalah usaha ekonomi produktif yang berdiri sendiri, yang dilakukan oleh orang perorangan atau badan usaha yang buka merupakan anak perusahan atau bukan anak cabang yang dimiliki, dikuasai atau menjadi bagian, baik langsung maupun tidak langsung, dari usaha menengah atau usaha besar yang memenuhi kriteria usaha kecil sebagaimana dimaksud dalam UU tersebut. Sedangkan usaha mikro adalah usaha ekonomi produktif yang berdiri sendiri yang dilakukan oleh perorangan atau badan usaha yang bukan merupakan anak perusahaan atau bukan cabang perusahaan yang dimiliki, dikuasai, atau menjadi bagian baik langsung maupun tidak langsung, dari usaha mikro, usah kecil atau usaha besar yangmemenuhi kriteria usaha mikro sebagaimana dimaksud dalam UU tersebut.

\section{Peran Marketplace Dalam Menunjang Pemasaran Produk UMKM di Indonesia}

Menurut Reza (2018), peran sektor Usaha Mikro Kecil Menengah (UMKM) dianggap sebagai tulang punggung ekonomi Indonesia. Setidaknya terdapat 88,8 persen berkontribusi dalam pertumbuhan ekonomi di Asia Tenggara. Di Indonesia, terdapat lebih kurang 59,2 juta pelaku UMKM dengan memberikan kontibusi 56 persen dari total perekonomian negara sampai saat ini. Namun, dari total UMKM tersebut, baru 3,97 persen juta UMKM yang sudah masuk online. Bagi sebagian besar pelaku usaha atau UMKM yang masih berjualan secara offline akan berusaha didorong untuk dapat masuk pasar online, sehingga UMKM Indonesia bisa merambah dunia digital dengan pasar yang lebih luas.

Untuk membangkitkan kondisi ini maka perlu adanya roadshow jangka panjang dengan menggelar 367 kegiatan dari 70 kota di Indonesia. Untuk mensukseskan gerakan ini, maka pemerintah bersama marketplace tersebut akan mempunyai rangkaian kegiatan bagi UMKM dibekali agar dapat go online, seperti mendorong pelaku UMKM offline ke online, active selling, pendampingan UMKM, Scale Up, hingga go internasional. Marketplace tersebut bisa menjadi gerbang untuk UMKM agar dapat go- 
online secara gratis. Mereka akan diberikan pelatihan dan pengetahuan mengenai bisnis online. Sehingga pelaku usaha atau UMKM tersebut bisa menjual barangnya secara global. Mengingat pengguna internet di Indonesia telah menembus angka 78\% dari seluruh pengguna internet yang ada dan telah memanfaatkan model belanja secara online di Indonesia.

\section{Marketplace berbasis kearifan lokal}

Kearifan lokal merupakan budaya yang dimiliki oleh masyarakat tertentu dan di tempattempat tertentu yang dianggap mampu bertahan dalam menghadapi arus globalisasi. Kearifan lokal mengandung nilai nilai yang dapat dijadikan sebagai sarana pembangunan karakter bangsa. Keterbukaan informasi dan komunikasi apabila tidak di persiapkan dengan baik maka akan berakibat pada hilangnya kearifan lokal sebagai identitas dan jati diri bangsa. Hal yang sama disampaikan oleh Yunus (2014) bahwa jati diri bangsa adalah watak kebudayaan (cultural character) yang berfungsi sebagai pembangunan karakter bangsa (national and character building).

Dengan diberlakukannya MEA pada tahun 2015, negara anggota ASEAN akan mengalami aliran bebas barang, jasa, investasi, dan tenaga kerja terdidik dari dan ke masingmasing Negara anggota ASEAN. Bagaimana Indonesia sebagai bagian dari komunitas ASEAN berusaha untuk mempersiapkan dan memanfaatkan peluang MEA, serta juga harus menjaga nilai- nilai kearifan lokal dalam menghadapinya. Market place lokal di Aceh diharapakan ikut berperan memajukan dan memperkuat sektor UMKM Aceh dengan menanam nilai kearifan lokal di sana. Diakui memang jutaan produk masuk yang berasal dari luar menjadi tantangan besar. Namun pertumbuhan produk khas yang memiliki nilai- kearifan lokal dalam sistem jual beli online seperti kejujuran dan lainnya harus terus di pupuk, dan masyarakat harus terus diberi dorongan dan dukungan untuk terus melakukan strategi bisnis agar berbisnis online dengan konsep kearifan lokal berimbang. Saat ini terdapat potensi besar yang wajib di gali di Aceh khususnya, karena jumlah masyarakat yang memiliki akses terhadap internet semakin besar sehingga sangat mungkin untuk menciptakan transaksi online di Aceh.
Tentunya moment ini sangat bagus apabila pelaku usaha kecil memanfaatkan marketplace sebagai media penghubung dengan konsumen dalam menawarkan berbagai jenis barang dan tidak hanya berorientasi pada bisnisnya namun juga harus memasukkan nilai kearifan lokal dalam setip transaksinya di marketplace. Ke depan, fenomena ini akan terus semakin meningkat dengan semakin berkembangnya teknologi dibidang e-commerce yang sangat menunjang segala bentuk perdagangan dan belanja online dalam memenuhi kebutuhan konsumen namun minim nilai kearifan local.

\section{Marketplace dalam perspektif kearifan lokal}

Kearifan lokal adalah identitas atau kepribadian budaya sebuah bangsa yang menyebabkan bangsa tersebut mampu menyerap, bahkan mengolah kebudayaan yang berasal dari luar/bangsa lai menjadi watak dan kemampuan sendiri (Wigunadika, 2018). Identitas dan Kepribadian tersebut tentunya menyesuaikan dengan pandangan hidup masyarakat sekitar agar tidak terjadi pergesaran nilai-nilai. Kearifan lokal adalah salah satu sarana dalam mengolah kebudayaan dan mempertahankan diri dari kebudayaan asing yang tidak baik. Kearifan lokal adalah pandangan hidup dan ilmu pengetahuan serta berbagai strategi kehidupan yang berwujud aktivitas yang dilakukan oleh masyarakat lokal dalam menjawab berbagai masalah dalam pemenuhan kebutuhan mereka. Dalam bahasa asing sering juga dikonsepsikan sebagai kebijakan setempat local wisdom atau pengetahuan.

\section{Metodologi Penelitian}

\section{Jenis Penelitian}

Pengembangan Penelitian ini termasuk dalam penelitian kualitatif deskripstif dan menurut Sukandarrumidi (2012) penelitian kualitatif deskriptif bertujuan untuk menjelaskan kondisi yang ada dan membuat korelasi, survey, studi kasus, studi pengembangan dan gambaran tentang gejala dalam masyarakat, yang berisi fakta untuk memecahakan permasalahan dalam penelitian.

\section{Tempat dan Waktu Penelitian}

Penelitian model marketplace berbasis kearifan lokal ini dilakukan di Kampus STMIK Indonesia 
Banda Aceh dan analisis data di lapangan terhadap model dan metode penelitiannya dilakukan dengan mewawancarai beberapa pelaku UMKM dan pengguna marketplace lokal di Kota Banda Aceh. Penelitian direncanakan dilakukan mulai awal Januari 2020 hingga akhir Maret 2020.

\section{Populasi dan Sampel}

Populasi dalam penelitian ini adalah seluruh pelaku usaha kecil di Kota Banda Aceh. Sampel dalam penelitian ini adalah pelaku usaha kecil yang aktif menggunakan marketplace selama dua tahun terakhir dalam proses pemasaran dan penjualan produk mereka di pasar online. Dari hasil penetapan sampel secara non random sampling tersebut, diperoleh sebanyak 173 responden yang umumnya adalah pelaku usaha kecil.

\section{Teknik Pengumpulan Data}

Teknik pengumpulan data menggunakan model interview dan kuisioner. Kuisioner yang diterapkan baik untuk uji coba lapangan menggunakan model kuisioner tertutup atau dengan kata lain sudah disediakan pilihan jawabannya untuk dipilih oleh responden. Pengumpulan data mutlak diperlukan untuk dianalisis pada tahapan selanjutnya

\section{Instrumen Penelitian}

Dalam mengumpulkan data, penelitian ini menggunakan interview dan angket penelitian atau kuesioner yang telah dibuat peneliti berdasarkan turunan dari teori yang digunakan yang selanjutnya dijadikan dalam kisi-kisi instrumen yang juga telah dikonsultasikan sebelumnya, dan kemudian instrumen tersebut divalidasi oleh ahli yaitu ahli proses pembuatan instrumen awal, proses evaluasi dan validasi, hingga instrumen final yang digunakan secara berurutan. Kisi-kisi instrumen dirancang berdasarkan simpulan dari teori-teori yang digunakan sebelumnya.

\section{Teknik Analisis Data}

Untuk menguji data dan menjawab permasalahan maka perlu di lakukan serangkaian pengujian yang nantinya dapat digunakan sebagai dasar keputusan dan bahan pembahasan sehingga permasalahan yang ada dapat ditemukan jawabannya. Model analisa yang digunakan disini adalah Uji Crosstabs, yakni sebuah model uji untuk menentukan dan menemukan ada tidaknya hubungan linier antara model marketplace berbasis kearifan lokal dengan target omzet yang ingin diraih oleh masingmasing pelaku usaha kecil di enam kecamatan kota Banda Aceh. Maka rumusan atau formula uji Crosstabs dapat ditampilkan secara utuh seperti yang tampak di bawah ini (Santoso, 2010):

Rumus uji Crosstabs, sebagai berikut:

$$
X^{2} p=\sum \frac{(f i j-E i j)^{2}}{E i j}
$$

dimana: The degrees of freedom are $(\mathrm{R}-1)(\mathrm{C}-1)$

\section{Hasil dan Pembahasan}

\section{Data Responden}

Tabel 1. Profil Responden

\begin{tabular}{|c|c|c|c|c|}
\hline Kecamatan & $\begin{array}{l}\text { Jumlah } \\
\text { Pelaku } \\
\text { Usaha }\end{array}$ & $\begin{array}{c}\text { Marketplace } \\
\text { Yang } \\
\text { Disuka }\end{array}$ & e Jenis Barang & $\begin{array}{c}\text { Pangsa } \\
\text { (Omzet) }\end{array}$ \\
\hline \multirow{4}{*}{ Baiturrahman } & \multirow{4}{*}{32} & \multirow{4}{*}{ Bukalapak } & Aneka & $46 \%$ \\
\hline & & & Makanan & $58 \%$ \\
\hline & & & Aneka Tas & $27 \%$ \\
\hline & & & T-shirt \& & $74 \%$ \\
\hline \multirow{3}{*}{ Jayabaru } & \multirow{4}{*}{28} & & Fashion Pria & $44 \%$ \\
\hline & & Tokopedia & Peralatan & $32 \%$ \\
\hline & & & Souvenir \& & $31 \%$ \\
\hline \multirow{4}{*}{ Meuraxa } & & \multirow{4}{*}{ Tokopedia } & Fashion & $22 \%$ \\
\hline & \multirow{3}{*}{30} & & Makanan \& & $37 \%$ \\
\hline & & & Perawatan & $21 \%$ \\
\hline & & & Pinjaman & $69 \%$ \\
\hline \multirow{3}{*}{ Bandarbaru } & \multirow{3}{*}{18} & & Produk & $24 \%$ \\
\hline & & Bukalapak & Fashion Pria & $33 \%$ \\
\hline & & & Barang & $41 \%$ \\
\hline \multirow{4}{*}{ Kutaraja } & \multirow{4}{*}{31} & \multirow{4}{*}{ Shopee } & Fashion & $22 \%$ \\
\hline & & & Fashion Bayi & $37 \%$ \\
\hline & & & Perlengkapan & $26 \%$ \\
\hline & & & Kecantikan & $38 \%$ \\
\hline \multirow{4}{*}{ Kuta Alam } & \multirow{4}{*}{34} & \multirow{4}{*}{ BliBli } & Herbal & $29 \%$ \\
\hline & & & Perabot & $21 \%$ \\
\hline & & & Mainan Anak- & $33 \%$ \\
\hline & & & Elektronik & $19 \%$ \\
\hline
\end{tabular}

\section{Hasil Uji Crosstabs}

Untuk memberikan gambaran nyata mengenai analisa dalam kajian pemasalahan dalam 
penelitian ini, berikut ditampilkan bentuk uji Crosstabs untuk menguji hubungan linier di enam kabupaten secara simultan, makna dari uji Crosstabs adalah bahwa angka capaian yang muncul di tabel 2 di bawah, menunjukkan tingkat capaian penjualan oleh pelaku usaha kecil ketika mereka merkiprah melalui marketplace dalam dua tahun terkahir. Tetunya angka capaian tersebut masih bersifat sementara, karena dihitung hanya dua tahun (tahun 2017 dan tahun 2018) terakhir ketika mereka mulai terlibat dalam marketplace saat memasarkan dan menjual produknya memalui online. Dimana hasil dua tahun tersebut tentunya akan berbeda di tahun-tahun berikutnya. Sehingga persepsi pelaku usaha diakumulasikan dalam sebuah skor pengumpulan data, sebagai landasan untuk melakukan pengujian. Hasil Uji Crosstabs tampak sebagai berikut:

Tabel 2. Hasil Uji Crosstabs * Kabupaten * Pencapaian_target Crosstabulation Count

\begin{tabular}{lccccc}
\hline \multicolumn{7}{c}{ Pencapaian Target Penjualan } & Total \\
& $\begin{array}{c}\text { Target } \\
\text { Tercapai } \\
100 \%\end{array}$ & $\begin{array}{c}\text { Target } \\
\text { Tercapai } \\
75 \%-50 \%\end{array}$ & $\begin{array}{c}\text { Tercapai } \\
\text { Hanya } \\
50 \%-30 \%\end{array}$ & $\begin{array}{c}\text { Target } \\
\text { Tercapai } \\
<30 \%\end{array}$ & \\
\hline Baitu & 12 & 8 & 4 & 8 & 32 \\
Jayab & 10 & 5 & 5 & 10 & 30 \\
Meur & 11 & 10 & 12 & 1 & 34 \\
Band & 9 & 10 & 8 & 1 & 28 \\
Kutar & 7 & 5 & 6 & 0 & 18 \\
Kuta & 14 & 9 & 2 & 6 & 31 \\
Total & 63 & 47 & 37 & 26 & 173 \\
\hline
\end{tabular}

Tabel 3. Chi-Square Tests

\begin{tabular}{rrrr}
\hline & Value & df & Asymp. Sig. (2-sided) \\
\hline Pearson Chi-Square & $1 y, / / 5^{n}$ & 15 &, 044 \\
Likelihood Ratio & 21,743 & 15 &, 032 \\
Linear-by-Linear Association &, 000 & 1 & 1,000 \\
N of Valid Cases & 173 & & \\
\hline
\end{tabular}

a. 18 cells $(75,0 \%)$ have expected count less than 5 . The minimum expected count is 37 .

Pada tabel 2 di atas dapat digambarkan kemampuan pelaku usaha kecil di enam Kecamatan di Banda Aceh dalam mencapai prosentase penjualan mereka melalui peran pasar online (marketplace), di kecamatan Baiturrahman sebagian besar pelaku usaha mampu mencapai target penjualannya menggunakan peranan marketplace, pencapaian target penjualan $100 \%$ paling tinggi kedua di kecamatan ini, kemudian yang paling tinggi pencapaian target 100\% penjualannya adalah Jayabaru, walaupun di Kecamatan tersebut masih ada pelaku usaha yang tingkat capaian penjualannya di bawah $30 \%$, pencapaian target penjualan $100 \%$ artinya semua barang yang dipasarkan laku terjual keseluruhan, sedangkan capaian penjualan di bawah 100\% artinya dari 100\% barang yang dijual pada akhir periode masih ada barang tersisa yang belum mampu diserap oleh pasar melalui penjualan online. Semakin kecil persentase penjualan berarti semakin besar stok barang yang tersisa di akhir periode. Pada tabel 2 di atas, terlihat jelas pelaku usaha yang sukses menafaatkan marketplace jumlah 63 orang $(36,42 \%)$ target penjualan $100 \%$ tercapai, 47 orang $(27,17 \%)$ target tercapai hingga maksimum 75\%. 37 orang pelaku usaha $(21,39 \%)$ tercapai hanya maksimum 50\% target penjualannya, dan sisanya sebanyak 26 orang pelaku usaha $(15,02 \%)$ hanya tercapai kurang dari $30 \%$ dari target. Target penjualan pelaku usaha yang tercapai dengan baik sampai dengan maksimum 75\% adalah 63,58\%. Angka ini sudah terbilang bagus karena nilainya di atas 50\%. Artinya secara keseluruhan dari pencapaian target penjualan, sebanyak 110 orang pelaku usaha sukses bermitra dengan marketplace dalam upaya memasarkan dan menjual produknya.

Pada tabel 3 jika amati dengan seksama, hasil uji Crosstbas nilai tingkat kesalahan (Asymp. Sig) kolom terakhir adalah $0,044<5 \%$. Berarti hasil uji Crosstabs tersebut menggambrkan secara nyata bahwa Ada hubungan linier antara antara kegiatan pemasaran dan penjualan melalui marketplace dengan jumlah omzet yang diraih pelaku usaha kecil di enam Kecamatan di Banda Aceh. Karena ada hubungan linier maka dapat disimpulkan marketplace memiliki hubungan linier atau nyata terhadap upaya pencapaian angka penjualan (target) pelaku usaha kecil dalam memasarkan dan menjual produk mereka melalui empat marketplace yang ada yaitu Bukalapak, Tokopedia, Shopee, dan Blibli.

\section{Pembahasan}

Sekarang telah diperoleh sebuah gambaran jelas, berdasarkan hasil uji ternyata keberadaan marketplace (Bukalapak, Tokopedia, Shopee, dan BliBli) memiliki peran dan kontribusi terhadap 
aktivitas pelaku usaha kecil di enam Kecamatan di kota Banda Aceh dalam upaya pemasaran, penjualan dan perluasan pasar mereka yang dilakukan secara online. Berarti ke depan semakin banyak pelaku usaha kecil yang menggunakan marketplace dalam memasarkan produk-produknya, akan sangat membantu upaya mereka dalam meningkatkan penjualan secara online dalam upaya meningkatkan market share mereka. Ini merupakan kenyataan yang baik bagi pelaku usaha kecil yang memiliki produk yang berpotensi dapat diterima oleh konsumen, dijual menggunakan marketplace. Berarti keberadaan marketplace merupakan salah satu alternatif yang baik untuk meningkatkan nilai penjualan ke depan.

\section{Kesimpulan}

Tidak dapat dipungkiri lagi bahwa keberadaan marketplace ternyata sangat membantu pelaku usaha kecil di enam Kecamatan yang ada di Kota Banda Aceh yaitu Baiturrarman, Jayabaru, Meuraxa, Bandarbaru, Kutaraja dan Kuta Alam. Dalam rangka meningkatkan penjualan mereka, selain dengan cara offline (penjualan non online), pelaku usaha kecil di Banda Aceh sebaiknya berusaha mencoba keberadaan marketpalce sebagai mitra dalam kegiatan pemasaran dan penjualan, karena di enam Kecamatan tersebut terbukti memiliki manfaat dan kontribusi bagi pelaku usaha kecil, ini merupakan moment yang baik bagi pelaku usaha kecil meraih jumlah konsumen menggunakan media online

\section{Daftar Pustaka}

Albi, M., \& Luqni, M. (2018). Perubahan Gaya Hidup Konsumtif Mahasiswa (ROA) Studiu Kasus Pondok Pesantren Mahasaiswa Universal Al Islamy Pengguna Online Shop Kelurahan Cipadung Kecamatan Cibiru Kota Bandung (Doctoral dissertation, Uin Sunan Gunung Djati Bandung).

Alfarizi, I. (2019). Trend Jual Beli Online Melalui Situs Resmi Menurut Tinjauan Etika Bisnis Islam (Doctoral dissertation, IAIN Bengkulu).
Anggono, R. M. (2020). Pengaruh kualitas fitur website, jenis layanan, iklan terhadap kepuasan konsumen di Tokopedia (Doctoral dissertation, Widya Mandala Catholic University Surabaya).

Arwiedya, M. R., \& SUGIARTO, S. (2011). Analisis Pengaruh Harga, Jenis Media Promosi, Resiko Kinerja, dan Keragaman Produk Terhadap Keputusan Pembelian Via Internet Pada Toko Online (Studi Kasus Pada Konsumen Toko Fashion Online yang bertindak sebagai Reseller yang ada di Indonesia) (Doctoral dissertation, Universitas Diponegoro).

Hadi Soeprayitno Putra, A. (2016). Aplikasi ECommerce Berbasis Web Terintegrasi Mobile Android. Journal of Undergraduate Thesis, Universitas Muhammadiyah Jember.

Handayani, M., \& Sholahuddin, M. (2017). Analisis Beberapa Variabel Yang Mempengaruhi Keputusan Pembelian Konsumen Melalui E-Commerce (Doctoral dissertation, Universitas Muhammadiyah SUrakarta).

Karmila, D., \& Rusda, D. (2019). EMarketplace Penjualan Dan Pemasaran Barang Furniture Pada Toko Mebel Menggunakan PHP dan Mysql Server. Jurnal Penelitian Dosen FIKOM (UNDA), 10(1).

Majid, B. W. (2017). Analisis Kepercayaan dan Persepsi Rantai Nilai Menurut Konsumen Pada E-Commerce (Doctoral dissertation, University of Muhammadiyah Malang).

Outletz. ID., (2018). 5 Alasan Penting Anda Perlu Mencoba Jualan di Marketplace. From https://outletz.id/5-alasan-pentinganda-perlu-mencoba-jualan-dimarketplace/

Permana, R., \& Hadi, A. F. (2019). Sales Management System Design And Promotion Media (Marketplace) Sales Of Umkm, Padang City. Jurnal KomtekInfo, 6(2), 155-159. 
Qomarudin, M. R. (2019). Tinjauan hukum Islam dan Perdata terhadap jual beli Sistem Mystery Box di Situs www. bukalapak. com (Doctoral dissertation, UIN Sunan Ampel Surabaya).

Qulub, M. (2019). Transaksi jual beli berbentuk undian di Serbu Seru Bukalapak menurut pandangan MUI Kota Malang dan hukum konvensional (Doctoral dissertation, Universitas Islam Negeri Maulana Malik Ibrahim).

Reza. (2018). Dorong UMKM, Kominfo Gandeng 6 Marketplace Indonesia. From https://www.liputan6.com/news/read/ 3488224/dorong-umkm-kominfogandeng-6-marketplace-indonesia.

Safirah, E. Studi Ekspolratif Terhadap Potensi Bubble Startup Digital Di Indonesia (Bachelor's thesis, Fak. Ekonomi dan Bisnis Uin Jakarta).

Santoso, S. (2010). Statistik parametrik. Elex Media Komputindo.

Setyaningrum, R., \& Tontowi, A. E. (2014). Studi Purchasing Power Parity\&Cost of Living Indicator sebagai Acuan Pemenuhan Kebutuhan Produk Berbasis Budaya.
Susanto, R. (2012). Strategi E-Commerce Melalui Pendekatan Business To Consumer Dalam Manajemen Usaha Kecil Dan Menengah Di Indonesia. Kajian Ilmiah Mahasiswa Manajemen, 1(6).

Utami, N. K. Y., \& Trisna, N. M. S. W. (2019, February). Kajian usability e-marketplace bluprin sebagai direktori bidang arsitektur dan desain interior dalam dunia digital. In senada (Seminar Nasional Desain Dan Arsitektur) (Vol. 2, pp. 589-597).

Utoyo, I. (2016). Sillicon Valley Mindset: Membangun ekosistem startup digital indonesia. Gramedia Pustaka Utama.

Widiana, E. M., Hidayati, K., \& Karsam, K. (2019). Kepuasan Pelanggan. Teoritik \& Empirik Strategi Pemasaran, 45. Penerbit Aseni, Papua.

Wigunadika, I. W. S. (2018). Pendidikan Karakter Berbasis Kearifan Lokal Masyarakat Bali. Purwadita: Jurnal Agama dan Budaya, 2(2), 91-100.

Yustiani, R., \& Yunanto, R. (2017). Peran Marketplace Sebagai Alternatif Bisnis di Era Teknologi Informasi. Jurnal Ilmiah Komputer dan Informatika (KOMPUTA), 6(2). 